\title{
IMPROVING THE PERFORMANCE OF POTATO CHIPS PRODUCTION LINE
}

\author{
Fouda, T $^{*}$ A. Derbala ${ }^{* *}$ M. Darwesh ${ }^{* *}$ M. Elkhodarey ${ }^{* * *}$
}

\section{ABSTRACT}

This study was carried out in potato chips production line to improve the performance of production line. The peeling device heat and control (Mod BP) potato batch peeler type was modified to suit the different varieties of potatoes were used and its performance was evaluated. Two different varieties of potato (Hermes and Lady Rosetta), harvested from two soil type (sand and clay), under using two peeling processes (conventional and modified). The measurements were taken before and after modified potato peeler to measure the performance of the peeling process and the quality of the final potato as chips. The results showed that when used modified potato peeler the peeling efficiency was increased by $3.1 \%$, the mechanical destruction of the potato tubers were decreased by $32.7 \%$, the peeling time of every batch decreased by 17.7 $\%$ so the peeler productivity per hour increased by $21.9 \%$ and the water consumption decreased by $17.6 \%$. The properties of the final product were improved as the oil content percentage was decreased by $2.4 \%$. That means dropping of use oil and processing time addition to have more healthy product.

\section{INTRODUCTION}

otatoes (Solanum tuberosumL.) are one of the essential food
crops in the world and are grown in more than 100 countries
under temperate, subtropical and tropical conditions. Its worldwide production in 2010 was close to 324 million tons and the plant was grown on approximately 19 million hectares. FAO, (2011). Maryam and Mohsen (2015) reported that, the potato plant is a staple in the food diet of many people around the world and ranks second after rice in terms of widespread global distribution. Approximately $34 \%$ of the total potato crop is produced in Asian countries.

\footnotetext{
*Prof. of Agric .Eng .Dept ., Fac. of Ag., Tanta. Univ.

**Assoc. Prof. of Agric. Eng. Dept., Fac. of Ag., Tanta. Univ.

***Postgraduate of Agric. Eng. Dept., Fac. of Ag., Tanta. Univ.
} 
Probably due to its high calorie content, potato has, throughout the years, been a main supplier of energy in people's food. The protein in potato is of a high biological quality, supplying 8 or 9 types of amino-acids which cannot be produced by human body. Abdollah and Amir (2013) pointed out that determination of physical properties of the potato, and their variations during long-term storage, is an important feature in achieving high product quality and consumer acceptance. Physical properties of potatoes (Agria, Satina, and Caesar cultivars), including surface area, volume, moisture content, weight, and three main diameters of tuber, were measured and then other properties, such as sphericity, roundness, geometric mean diameter, volume mean diameter, aspect ratio, effective diameter, and real density during storage time, were calculated Trehan $\boldsymbol{e t}$ al., (2009) mentioned that one of the main considerations during tubers selection as raw processing materials is the potato cultivar. Additionally, environmental conditions, cultivation methods, handling during harvesting and storage also play an important role in determining the quality of processed products. Miranda and Aguilera, (2006) noted that Potato slices for chips are commonly cut thin (1.27-1.78 mm thick) and fried until the water content is reduced from $75-80 \%$ to $1-2 \%$ wet basis . Troncoso, et al., (2009) found that vacuum frying significantly increased the oil content of potato chips, decreased color and texture parameters, and improved both flavor and overall quality.

One of the factors affecting the quality of potato chips is the physical characteristics of the potato from which it is made as not all potato varieties will produce high quality chips. Potato chips makers source potatoes from different locations during different seasons and thus may encounter substantial variability in the physical characteristics of the raw potatoes that could affect the performance of the production line and the final chip quality.

The objective of this study was to improve the performance of the production line by modifying the potato peeler to minimize peeling losses and amount of water spraying washes also maximize the total efficiency of the production line addition to evaluate the impact of the physical and mechanical characteristics of potato samples selection to suite potato chips production. 


\section{MATERIALS AND METHODS}

The study was carried out in Special factory of making potato chips at Quesna, EL-Menofeya Governorate, Egypt during a period from JAN 2015 to JAN 2016. To evaluate and improve the performance of potato chips production line. Also to test the modifying of the potato peeler under different parameters processed to minimize peeling losses, peeling time and amount of water spraying washes, addition to maximize the productivity and total efficiency of the production line.

\section{Potato variety}

Using different varieties of potato (Hermes and Lady Rosetta), (Solanum tuberosumL.). A comparison between the potato varieties used in the experiment as shown in Table 1 and Fig, 1 and 2

Table (1): The properties of potato varieties used in the experiment

\begin{tabular}{|c|c|c|}
\hline Potato variety & Lady Rosette & Hermes \\
\hline Tuber shape & round & round oval \\
\hline Skin color & red & Yellow \\
\hline Flesh color & pale yellow & Yellow \\
\hline Eye depth & shallow & medium depth \\
\hline Maturity & medium early & medium early \\
\hline Yield & High & High \\
\hline Dry matter & high & Reasonable \\
\hline Cooking type & floury & Floury \\
\hline Use & Chips & Chips \\
\hline
\end{tabular}

Fig. (1) Lady Rosetta potato variety

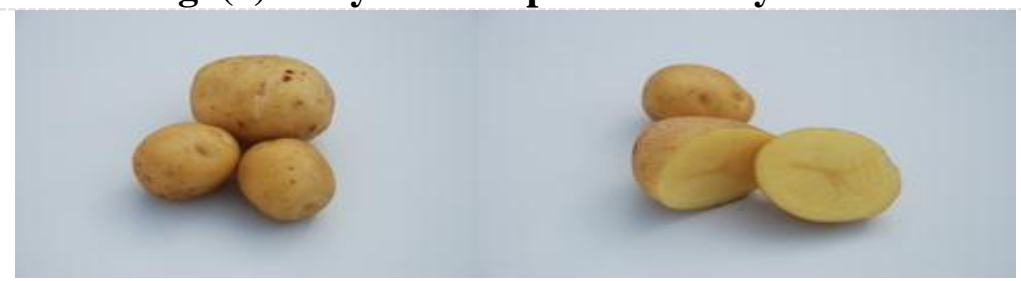

Fig. (2) Hermes potato variety 


\section{Potato chips production line}

The production line consists of a dynamic system of interdependent stages linked together to convert the potato into a chip as showing in Fig.3

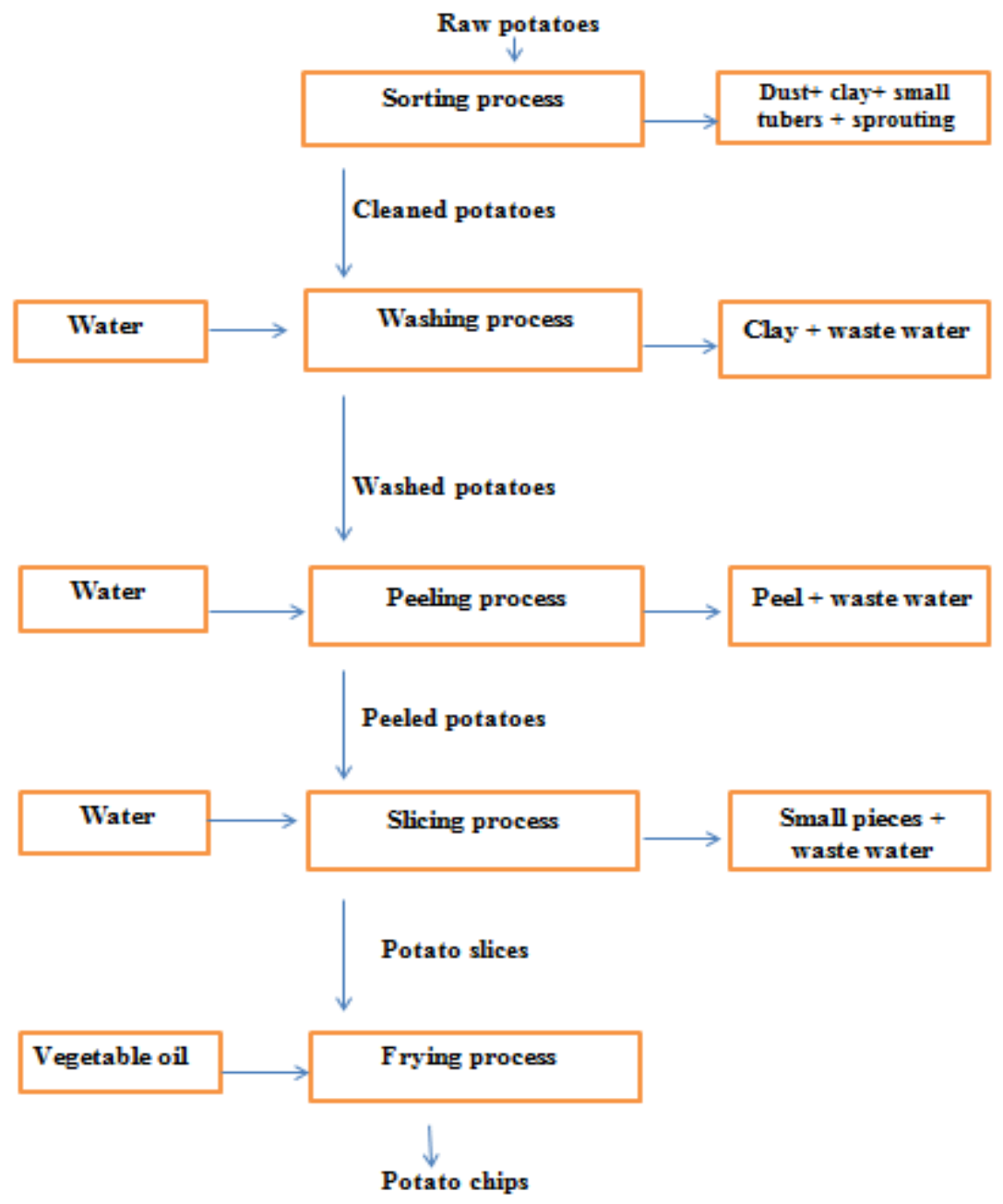

Fig. (3) Diagram of potato chips production stages

\section{Modified peeling machine}

For the processing of potatoes in to potato chips, removal of peel is an important unit operation. So, peeling device (Heat and Control Mod BP) potato batch peeler type was modified as showed in (Fig. 4) to suit the different varieties of potatoes and its performance was evaluated. The main parts of the machine are a peeling drum and a water spraying unit. 
The peeling drum inside surface covered with emery paper to detach peel from potatoes by abrasion. The water spraying unit washes the potatoes and simultaneously peel is removed from the drum through the perforation along with the flow of water.

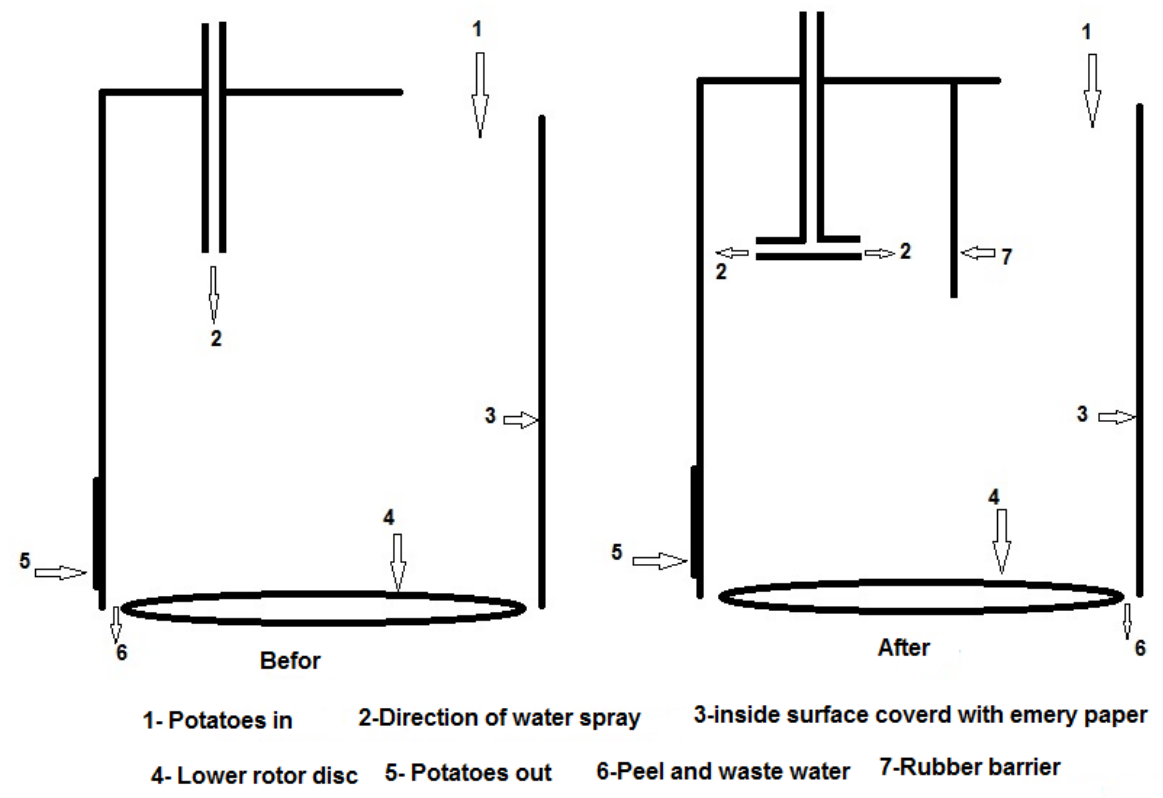

Fig (4). Peeling chamber before and after modifying

\section{Experimental Procedures:}

-Peeling processes (conventional and modified).

-Different varieties of potato (Hermes and lady Rosetta)

-Harvested from soil type (sand and clay),

\section{Potato samples}

In this study four potato samples comprising two potato varieties (Hermes, lady rosette) growing in two land type (clay and sand) were used. The samples were coded P1, P2, P3, and P4 as shown in Table 2. Physical properties of each sample (solid content, dust content, small tubers content were measured before used in processing.

Table.2. The coded potato samples were used.

\begin{tabular}{|l|l|l|l|l|}
\hline Treatments & \multicolumn{1}{|c|}{$\boldsymbol{P 1}$} & \multicolumn{1}{|c|}{$\boldsymbol{P 2}$} & \multicolumn{1}{c|}{$\boldsymbol{P 3}$} & \multicolumn{1}{c|}{ P4 } \\
\hline varieties & Hermes & Hermes & Lady Rosette & Lady Rosette \\
\hline land type & Clay & Sand & Clay & Sand \\
\hline
\end{tabular}




\section{Experimental measurements:}

-Physical properties of potato tubers (Shape index, volume, the geometric mean diameter, sphericity and surface area of potato tubers)

-The potato chips processing stages (sorting efficiency, washing efficiency peeling performance)

- Quality of the potato chips production evaluated by oil content of final product

\section{- Measuring physical properties of potato tubers}

A digital slide caliper of accuracy of $0.01 \mathrm{~mm}$ was used for measuring the three axis of tuber (the major axis as tuber length (L-mm), the intermediate diameter as tuber width (D-mm), and the thickness of tuber (T-mm). Shape index, volume, the geometric mean diameter, sphericity and surface area of potato tubers was taken according ( Mohsenin, 1986) Shape index: Shape index of the measured samples was calculated using the following formula: Shape index $(\mathrm{I})=\frac{L}{\sqrt{D T}}$

Volume of potato tubers: The nearest mathematical expression for the volume of potato tubers of the two varieties as follows:

$$
V \text { cal }=(\pi / 6)(L D T) \text {. }
$$

Where: $V \mathrm{cal}=$ calculated volume of individual tuber, $\mathrm{mm}^{3}$;

The geometric mean diameter $(\mathrm{Dg})$ : The geometric mean diameter was calculated by using the following equation:

$$
\mathrm{Dg}=(\mathrm{LDT})^{0.333}
$$

Sphericity: of the tuber was determined by the following formula

$$
\text { Sphericity }(\mathrm{S})=(\mathrm{Dg} / \mathrm{L}) \times 100
$$

Where, Dg is the geometric mean diameter of the tuber

Surface area (A): Surface area was determined by the following formula:

$$
\mathrm{A}=\pi \mathrm{Dg}^{2}
$$

\section{- Measuring the performance of the processing stages}

-Sorting efficiency: Sorting efficiency can be calculated by using the following formula. Sorting efficiency $=\frac{W 1-W 2}{W 1} * 100 \%$

Where: $\mathrm{W}_{1}$ Mass of the total sample, $\mathrm{W}_{2 \text { : }}$ Mass of the foreign matter which removed by sorting (dust-clay-spouting). 
-Washing efficiency: The washing efficiency was calculated by (Scott et al., 1981).

$$
W E=\frac{\mathrm{SR}}{\mathrm{SA}} * 100, \%
$$

Where: WE $=$ Washing efficiency, \%.

$\mathrm{SR}=$ Mass of foreign materials removed by washing $=$ Mass of sample before washing - mass of sample after washing, $\mathrm{g} / \mathrm{kg}$.

$\mathrm{SA}=$ Mass of foreign material attached, which was estimated by, hand washing of 50 samples of fruits to full cleaning and weighing the foreign materials attached with one $\mathrm{kg}$ of fruits $(\mathrm{g} / \mathrm{kg})$.

-The peeling efficiency: were determined by using the following formula (k.singh and shukla 1994)

$\mathrm{F} 1=$ fraction of peel in raw potatoes

$$
\text { Peeling efficiencey }=\frac{\mathrm{F} 1-\mathrm{F} 2}{\mathrm{~F} 1} * 100
$$

$\mathrm{F} 2=$ fraction of peel in peeled potatoes

-Mechanical destruction of potato tubers: can be calculated by using the following formula.

$$
\text { Mechanical destruction }=\frac{W 2}{W 1} * 100
$$

Where: $\mathrm{W}_{1}$ Mass of the total sample of potatoes.

$\mathrm{W}_{2}$ : mass of small pieces of tubers, which destroyed by peeling.

\section{-Measuring the potato chips quality}

Quality of the potato chips production evaluated by determine the oil content of final product.

-The oil content of potato chips: can be determine by using Soxtec System HT extraction unit (Pertorp, Inc., Silver Spring, MD, USA) with petroleum ether as the solvent (AACC, 1986).

\section{RESULTS AND DISCUSSION}

The discussion will cover the obtained results under the following heads.

\section{-Physical properties of potato samples}

The physical properties of potato samples which used to evaluate the potato chips production line such as length (L), width(D) ,thickness (T) ,shape index(I), Sphericity (S), Geometric mean diameter (DG), surface area(A) and 
calculated volume(V) where discussed the results obtained from measuring 100 potato tuber from each sample was showed in Table (3) .

Table (3):Some physical properties of potato samples

\begin{tabular}{|c|c|c|c|c|c|c|c|c|}
\hline Treatmen & $\boldsymbol{L}, \boldsymbol{m m}$ & $\boldsymbol{D}, \boldsymbol{m m}$ & $\boldsymbol{T}, \boldsymbol{m m}$ & $\boldsymbol{I}$ & $\boldsymbol{S}$ & $\boldsymbol{D G}, \boldsymbol{m m}$ & $\boldsymbol{A}, \boldsymbol{m m}^{\mathbf{2}}$ & $\boldsymbol{V . m m}^{\mathbf{3}}$ \\
\hline P1 & 94.87 & 53.33 & 44.62 & 1.98 & 63.77 & 60.37 & 11737.63 & 124749.92 \\
\hline P2 & 93.34 & 64.00 & 56.09 & 1.69 & 74.30 & 67.50 & 14695.29 & 173961.12 \\
\hline P3 & 79.47 & 62.69 & 60.98 & 1.32 & 84.46 & 66.13 & 14319.91 & 169391.44 \\
\hline P4 & 83.83 & 72.51 & 62.32 & 1.26 & 86.34 & 72.05 & 17143.77 & 225795.62 \\
\hline
\end{tabular}

\section{- Sorting efficiency evaluating}

Fig (5) showed the relationship between the potato samples and sorting efficiency it was showed that the highest value of sorting efficiency was $61.72 \%$ in $\mathrm{p} 1$ and the least value was $44.45 \%$ in $\mathrm{p} 2$.

\section{-Washing efficiency evaluating}

Fig (6) showed the relationship between the potato samples and washing efficiency it was showed that the highest value of washing efficiency was $100 \%$ in p2 and p4 were the least value was $80 \%$ in p1.

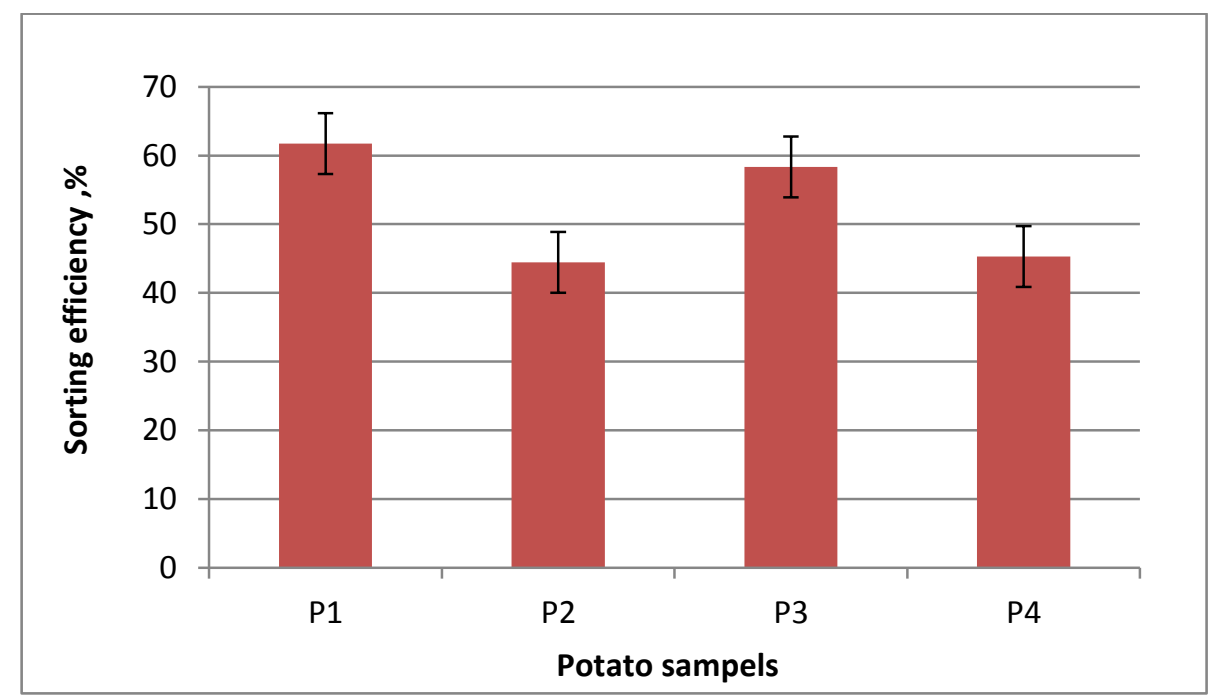

Fig. (5) The relationship between potato samples and sorting efficiency. 


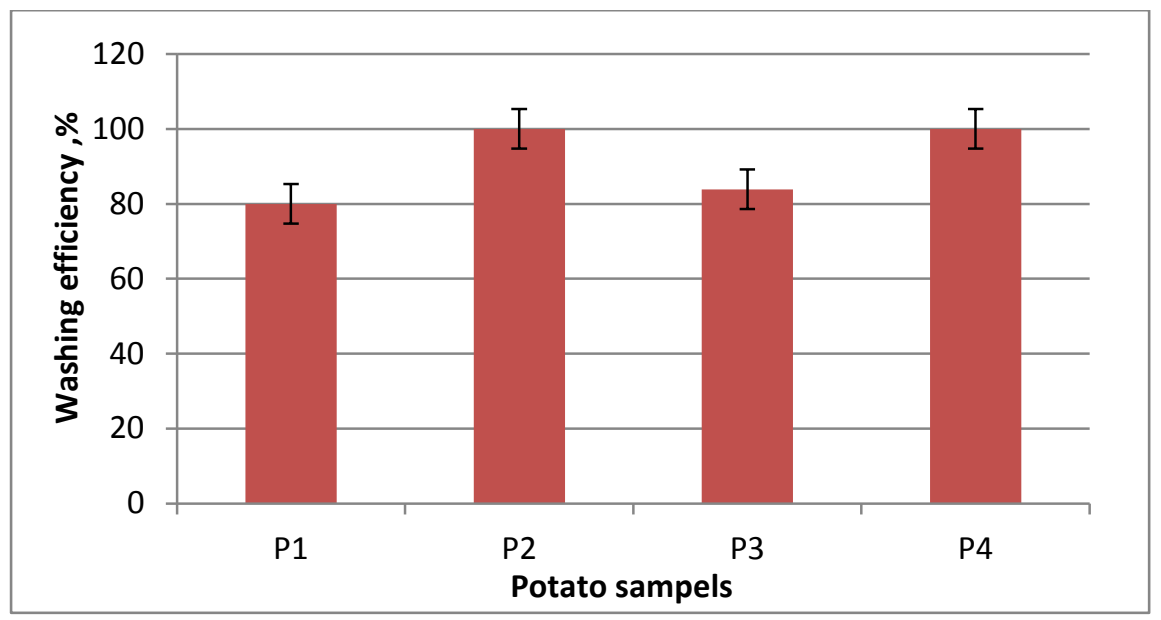

Fig. (6) The relationship between potato samples and washing efficiency

\section{- Effect of modifying the peeler on peeling performance -Peeling efficiency}

Fig (7) showed the effect of modifying the potato peeler on the peeling efficiency of potato samples it shows that peeling efficiency increased after modifying the peeler by $2 \%, 3 \%$,4and $3 \%$ in p1,p2,p3, and $\mathrm{p} 4$ respectively.

\section{- Mechanical destruction percentages during peeling}

Fig (8) showed the effect of modifying the potato peeler on mechanical destruction of potato tubers during the peeling process it shows that the mechanical destruction decreased after modifying the peeler by $37.9 \%$, $38.6 \%, 34.07 \%$, and $20.4 \%$ in p1, p2, p3, and p4 respectively.

\section{-Peeling time}

Fig (9) showed the effect of modifying the potato peeler on the peeling time per one batch of potatoes $(25 \mathrm{~kg})$ to reach the required peeling efficiency it shows that the peeling time decreased by 10 seconds in P2 and 5 seconds in the other samples.

\section{- Peeler productivity}

Fig (10) showed the effect of potato peeler modifying on the peeler productivity the amount of peeled potatoes per hour increased by 321.4 $\mathrm{kg}$ in $\mathrm{p} 1,750 \mathrm{~kg}$ in $\mathrm{p} 2,600 \mathrm{~kg}$ in $\mathrm{p} 3600$ and $\mathrm{kg}$ in $\mathrm{p} 4$. The peeler productivity for all samples increased by average $567.8 \mathrm{~kg}$ potatoes per hour with average percentage by $21.9 \%$. 


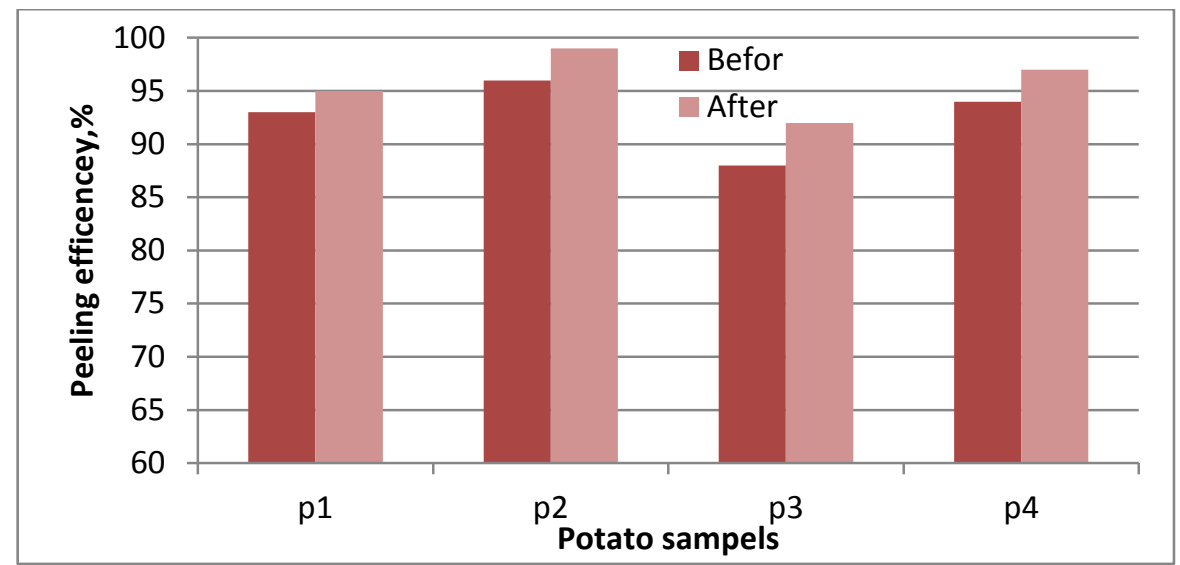

Fig. (7) Effect of modifying the peeler on peeling efficiency

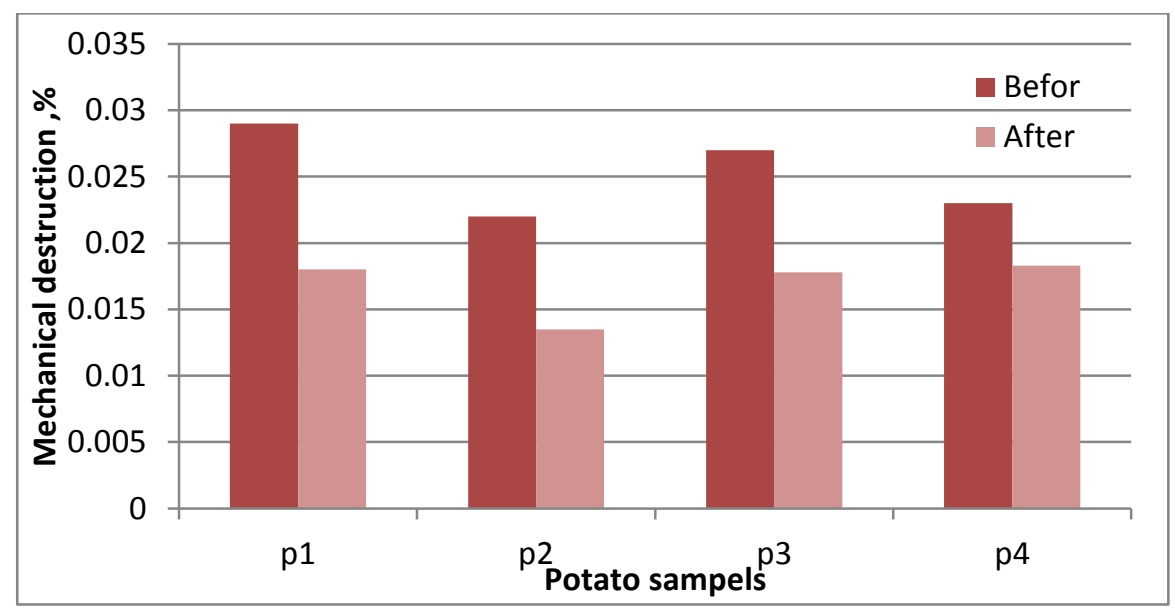

Fig. (8) Effect of modifying the peeler on mechanical destruction

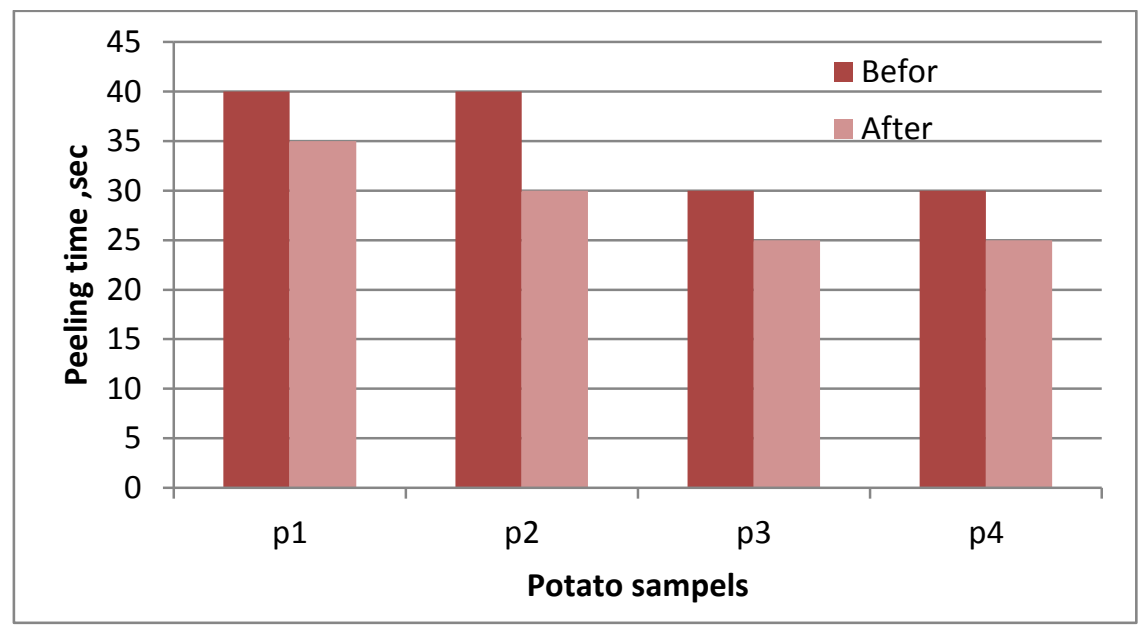

Fig. (9) Effect of modifying the peeler on the peeling time 


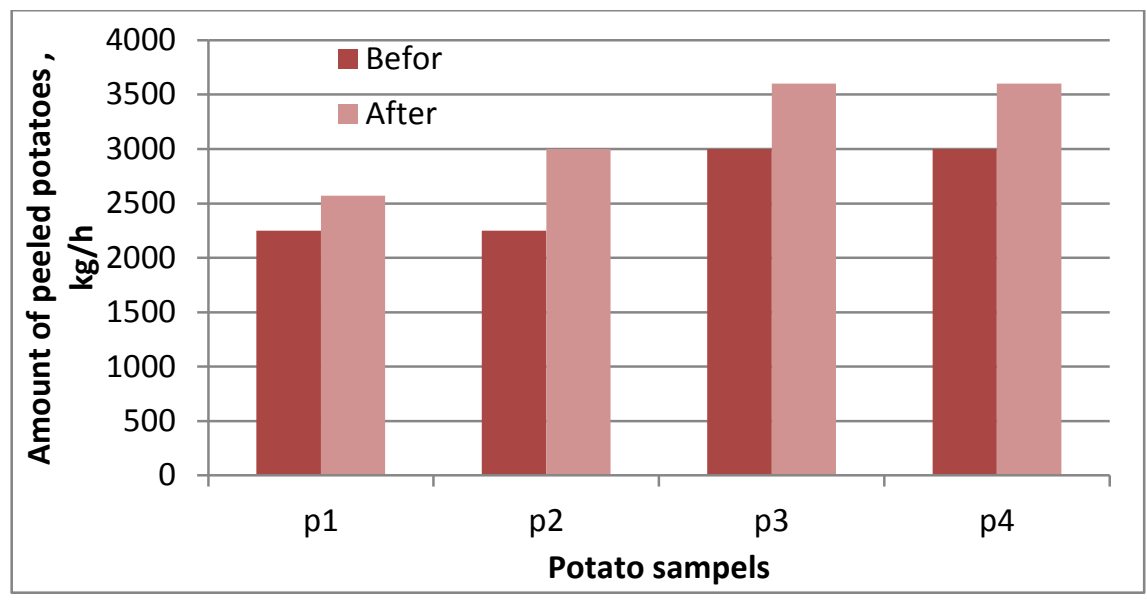

Fig. (10) Effect of the peeler modifying on the productivity

\section{-Water consumption}

Fig (11) showed the effect of modifying the potato peeler on the water consumption before and after modifying it shows that the water consumption decreased by $12.5 \%$ in $\mathrm{p} 1,25 \%$ in $\mathrm{p} 2,16.6 \%$ in $\mathrm{p} 3$, and 16.6 in $\mathrm{p} 4$. The average percentage of saving water in all samples was $17.6 \%$.

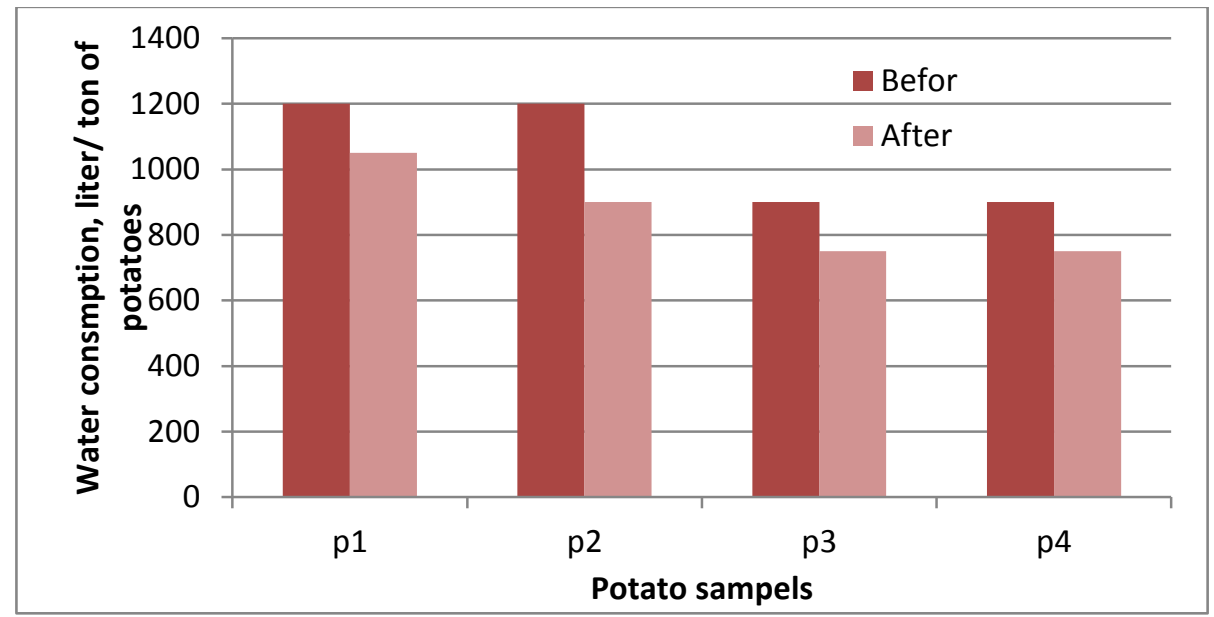

Fig. (11) Effect of modifying the peeler on water consumption

\section{-The potato chips oil content}

Fig (12) showed the effect of modifying the potato peeler on the oil content percentage of the potato chips as a final product it shows that oil 
content percentage decreased by $2.8 \%, 2 \%, 3.1 \%$, and $1.8 \%$ in $\mathrm{p} 1, \mathrm{p} 2, \mathrm{p} 3$, and 44 respectively under the same condition of slicing and frying process.

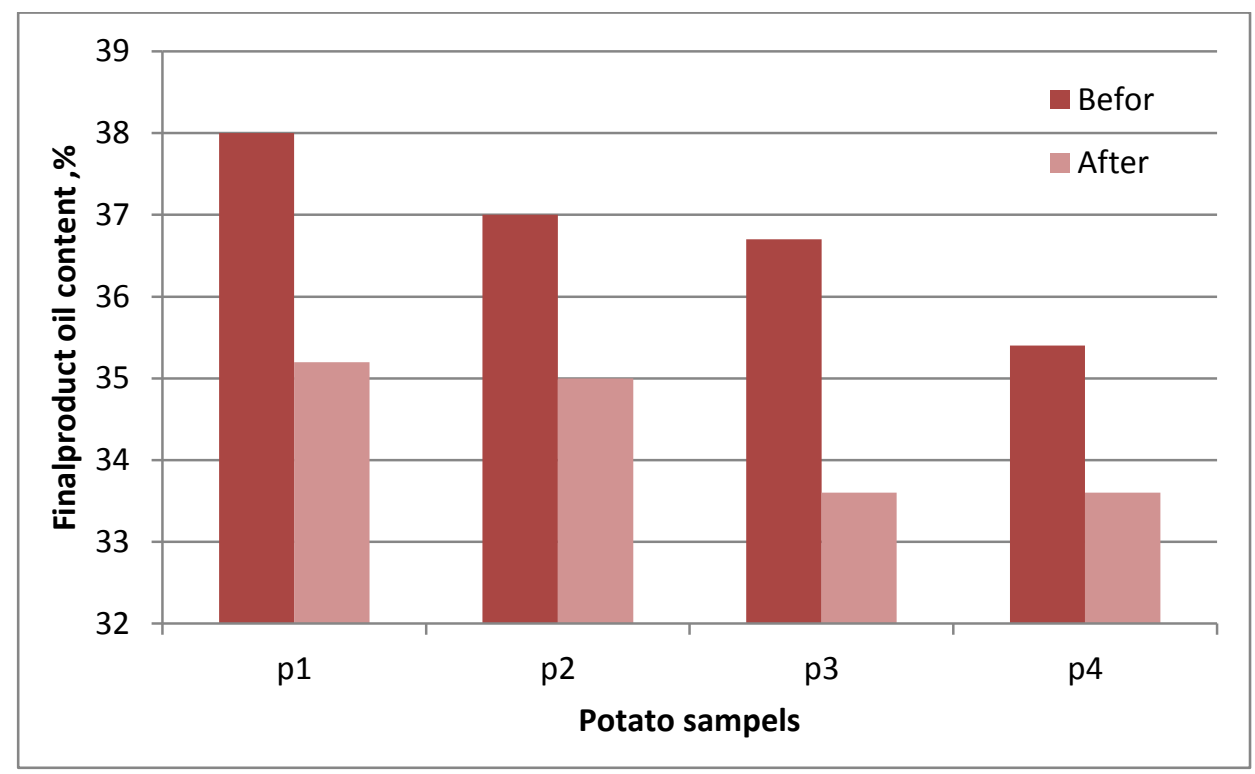

Fig. (12) Effect of modifying the peeler on oil content of the final product

\section{CONCLUSION}

The experimental work was executed in Special factory of making potato chips. The performance of the production line and modifying the potato peeler leads to maximize the peeling efficiency by $3.1 \%$, minimize the mechanical destruction of potato tubers during the peeling process by $32.7 \%$, minimize the peeling time per one batch by $17.7 \%$ Which led to maximize the productivity of the peeling device by $21.9 \%$ and minimize the amount of needed water consumption for peeling by $17.6 \%$, also the quality of the final product was improved as the oil content percentage was decreased by $2.4 \%$ that mean reducing the raw materials, reducing processing time and have more healthy product.

\section{REFERENCES}

AACC (1986). Approved Methods of the American Association of Cereal Chemists. AACC, Minneapolis, MN. 
Abdollah Golmohammadi and Amir H. Afkari-Sayyah (2013).long term storage effects on the physical properties of the potato. International Journal of Food Properties, 16:104-113

Corbo M, Speranza B, Campaniello D, D'Amato D, Sinigaglia M (2010) Fresh-cut fruits preservation: current status and emerging technologies. In: Mendez Vilas A (ed) Current research, technology and education topics in applied microbiology and microbial biotechnology. Formatex Research Center, Badajoz, pp 1143-1154

FAO, 2011.FAOStat: Crops Production.

http://faostat.fao.org/site/567/DesktopDefault.aspx?

PageID=567\#ancor. Accessed on January 2012.

K. K. Singh and B. D. Shukla(1994) Abrasive Peeling of Potatoes .Journal of Food Engineering 26 (1995) 431-442.

Maryam Tavakoli, Mohsen Najafzadeh 2015.Application of the Image Processing Technique for Separating Sprouted Potatoes in the Sorting Line. Journal of Applied Environmental and Biological Sciences (Maryam Tavakoli, Mohsen Najafzadeh 2015).

Miranda M, Aguilera JM. (2006). Structure and texture properties of fried potato products. Food Reviews International. 22:173-201.

Mohsenin, N.N. (1986). Physical properties of plant and animal materials. Gordon of Breach science publishers, Neaw York.

Scott, J. M.; D. J. Dunsmore and M. D. Keegan. 1981. Spray nozzle performance in cleaning food equipment. Trans. ASAE. 2 (3): 526- 536.

Trehan, S.P., S.K. Pandev and S.K. Bansal, 2009. Potassium Nutrition of Potato Crop - Indian Scenario.

http://www.ipipotash.org/en/eifc/2009/19/2. Accessed on January 2012

Troncoso, E. \&Pedreschi, F. (2009). Modeling water loss and oil uptake during vacuum frying of pre-treated potato slices. LWT-Food Science and Technology, 42, 1164-1173. 


\section{الملخص العربيى \\ تحسين اداء خط إنتاج شرائح البطاطس

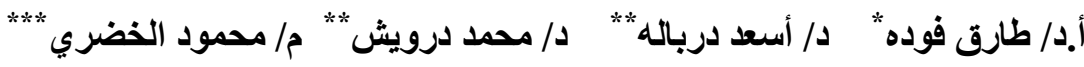

أجريت هذة التجربة فى أحد المصانع الخاصة بتصنيع بطاطس الثيبس فى قويسنا بمحافظة المنوفية

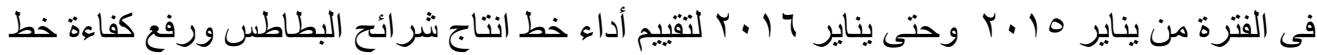

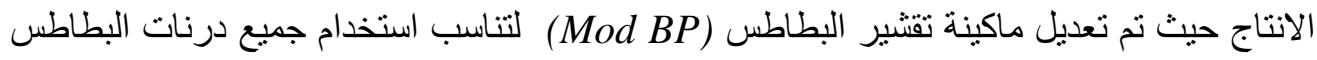
حيث تم در اسة بعض الخو اص الفزيائية لصنفين من البطاطس و اجريت الدر اسة تحت العو امل التالية:

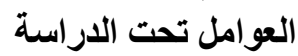

1- ـ صنفين من البطاطس ذات المو اصفات التصنيعية العالية ( هيرميس - ليدى روزيتا ).

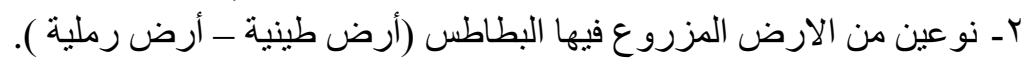

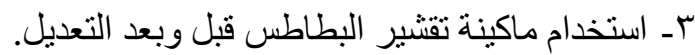

القياسات

ـ قياسات للمواصفات الهندسية للارنات المستخدمة فى التصنيع : وتشمل الطول و العرض و السمك

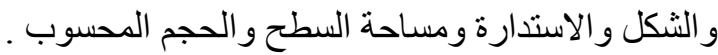
ـ قياس كفاءة مرحلة التنظيف و الفرز

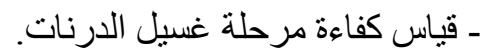
ـ قياس أداء ماكينة التقشير قبل وبعد التعديل. ـ قياس خواص الجودة للمنتج النهائى بعد القلى ودراسة نأثئير تعديل ماكينة التقتير على خواص المنتج النهائى . النتائج :يمكن تلخيص النتائج المتحصل عليها كالاتى التئ اـ تأثير الخواص الفزيائية للارنات علي كفاءة التنظيف والفرز وكائياءة الغسيل و أداء ماكينة التقتير

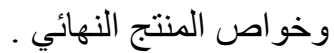
r- و أظهرت النتائج أن استخدام الآلة المعدلة أحدث تأثيرا ايجابيا على كفاءة التقثير حيث زادت بنسبة

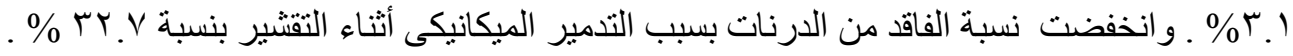

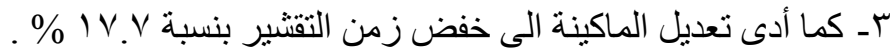

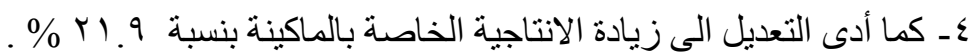

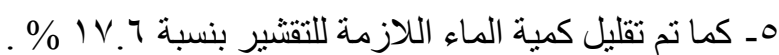

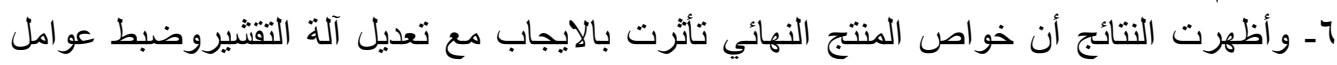

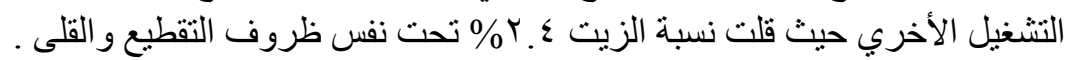

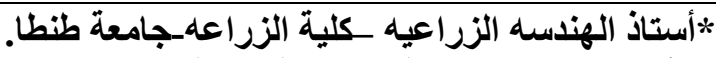

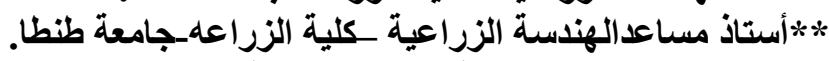

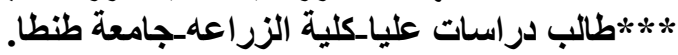

